\title{
On Appeal: Courts, Lawyering, and Judging
}

On Appeal: Courts, Lawyering and Judging. By Frank M. Coffin. New York and London: W.W. Norton \& Co., 1994. Pp. xix, 373. \$27.50.

\section{James L. Oakes ${ }^{\dagger}$}

Frank Coffin has done it again. With his The Ways of a Judge in 1980 he shed light on the subject of judging-particularly federal appellate judging - for laymen and lawyers, for law students, and for those in journalism and politics. With his new On Appeal, ${ }^{2}$ Judge Coffin has shed more light and made some new points. In addition to writing in understandable, sturdy New England prose for the layman or the lawyer who is not regularly engaged in the appellate process, Judge Coffin-perhaps pointedly, perhaps by accident-has directed this new work at his fellow judges, at least a good portion of it. As Judge Coffin quite openly suggests in reference to oral argument, "By their questions and comments to counsel, judges telegraph their concerns and preferences to the other judges. Oral argument is really the first stage of the conferencing among the judges." As one reads, particularly in Judge Coffin's chapters on "Collegiality," on "Judging Appeals," and on the "Future," it becomes clear that he is talking to his fellow appellate judges across the country and to those district judges who occasionally sit on the court of appeals. While, candidly, I did not expect to receive that many insights into our art-it certainly is not a science-of appellate judging, I was pleasantly otherwise surprised. I also received some new insights into the judge/law clerk relationship with which I thought I had long since fully acquainted myself.

But, first things first. The structure of the book is fairly simple. Chapter One introduces us to a typical "Day in Court"-a typical day in the First Circuit courtroom, with one en banc case and half-a-dozen other civil and

* Senior Circuit Judge, U.S. Court of Appeals for the First Circuit.

Senior Circuit Judge, U.S. Cour of Appeals for the Second Circuit.

1. Frank M. COFfin, The Ways of a JuDge: Reflections from the Appenlate BeNch (1980) [hereinafter WAYS OF A JUDGE].

2. FranK M. COFFIN, ON APPEAL: COURTS, LAWYERING AND JUDGiNG (1994) (hereinafter ON APPEALl.

3. Id at $132-33$.

4. Id. ch. 11.

5. Id. chs. 12-14.

6. Id. ch. 15. 
criminal cases. Chapter Two gives us the world picture by discussing the civil law appellate tradition-quite different, of course, from our own, as in other countries many issues on appeal are heard de novo. The English tradition and the overall United States tradition, as the Judge points out, are in a state of flux. A historical background of appellate justice is properly relegated to an appendix. In Chapter Three-pointedly titled "The State-Federal Court System: 'One Whole' "- the judge, with the help of charts, numbers, and analysis, puts the federal courts in their appropriate complementary rather than primary place, of which more later. Chapter Four tells us about "chambers," both of what they consist and a little of their inhabitants, the "family," namely, the secretary and law clerks; of this, more later also. Chapters Five through Eight take us through the appellate process, from the lawyer's office to briefs to oral argument (i.e., "Conversing with the Court") to and through the judges' conference. Chapters Nine, Ten, and Eleven are devoted to opinions, including organizing the workload in doing an opinion, working with law clerks, and working with one's fellow judges. Chapters Twelve, Thirteen, and Fourteen are devoted to the broader issues of judging appeals and how we go about deciding cases: the quest for legitimacy, sailing in familiar waters-that is to say, the generality of cases, those often decided without disagreement among judges "of even widely varied social, economic, and political backgrounds," and finally dealing with those cases in which ideology may be involved-that is to say, navigating in the "uncharted depths" of judging. The final chapter of the book is devoted, quite properly, to the future.

So much for structure-a structure nicely leavened, I might say, with one drawing per chapter amusingly done by the author's artist-designer son Douglas; every judge needs such a member of the family, one who can shed light, perhaps a little impertinently. Not having had one myself, I have had to rely on the all too occasionally impertinent law clerk who can keep us all in stitches with her drawings, her imitations of lawyers and judges alike, and her one-liners. ${ }^{8}$ I would rather talk about the things the book does, and perhaps even mention one or two that it does not do.

First, and most important, is Judge Coffin's Chapter Three, to which he alludes from time to time, emphasizing the "One Whole" language in The Federalist No. 82, where Alexander Hamilton-following up on the analysis of No. 81-foresaw that the national and state systems of courts would be just that: one whole. ${ }^{9}$ Judge Coffin points out that the realms of the dual-court system "intersect and overlap in a number of important ways." 10 Numerous federal cases, for example, involve or turn on state law; even federal

7. Id. at 253 .

8. I do not know why it is, but the three such clerks who stand out in my mind were all stars in the Columbia Law Revue.

9. THE FEDERALIST Nos. 81, 82 (Alexander Hamilton).

10. ON APPEAL, supra note 2, at 46. 
constitutional concepts such as "liberty" and "property" turn on state law expectations, some would say to too great a degree. " He points out that it is in state courts that by far most of the nation's litigation is decided, with the huge size of the state court component seldom being appreciated. Chief Judge Judith S. Kaye of the New York Court of Appeals made this point in the December 13, 1994 edition of The New York Times in an op-ed piece entitled Federalism Gone Wild. ${ }^{12}$ There she said that more than ninety-seven percent of all litigation is handled by the states, pointing out that under current trends, while more than one million cases a year will be filed in the federal system by the year 2020, more than one hundred million will be filed in the state systems. Judge Kaye took to task the recent draft of the proposed long-range plan for the federal courts released last year by the Committee on Long Range Planning of the Judicial Conference of the United States ${ }^{13}$ for seeming to suggest that "as long as the whole system is in trouble, why not at least save the Federal courts?"14 She concluded, "A solution that eases the burden on the Federal courts without taking into account the effect on the state court system is no solution at all."

But he goes beyond this to say, "The practitioner of today, and particularly tomorrow, is well advised to rethink conventional litigation strategy.... [S]uch strategy automatically dictated either bringing a case in or removing one to a federal court, [but] it is vulnerable." ${ }^{16}$ He points to the handling of complex litigation involving numerous forms and many parties in both federal and state courts-or even by consolidation in a state cour, as suggested by the American Law Institute. ${ }^{17} \mathrm{He}$ points out how, in state court systems with intermediate appellate courts, there may be more flexibility for review, say, of interlocutory orders, with courts of last resort having discretionary review. ${ }^{18}$ And of course he points to the literally hundreds of state court opinions declaring federal constitutional minimum standards insufficient under more stringent state constitutional requirements. ${ }^{19}$

11. See, e.g., Cleveland Bd. of Educ. v. Loudermill, 470 U.S. 532, 541 (1985); Baand of Regents v. Roth, 408 U.S. 564, 587-89 (1972) (Marshall, J., dissenting).

12. Judith S. Kaye, Federalism Gone Wild, N.Y. TMMES, Doc. 13. 1994, al A29.

13. Committee on long Range Planning. Judicial Conference of the U.S., Proposed losg RaNGe Plan for the Federal Courts: Draft for PUblic Comment (1994) thereinafter Proposed PLAN].

14. Kaye, supra note 12, at A29.

15. Id.

16. ON APPEAL, supra note 2, at 50-51.

17. Id. at 51-52; see also AMERICAN LAW INSTITUTE. COMPLEX LMTGATION PROJect 208-09 (Proposed Final Draft Apr. 5, 1993).

18. ON APPEAL, supra note 2, at 56-59.

19. Id. at 60-61; see also William J. Brennan, State Constiturions and the Protection of Individual Rights, 90 HARV. L. REV. 489 (1977); James L. Oakes, State Courts in a Time of Federal Consurutional Change, in RECENT DEVElopMENTS IN STATE CONSTITUTIONAL LAw (PLI Litig. \& Admin. Practice Course Handbook Series No. 277, 1985) (discussing Vermont cases). 
On the subject of diversity jurisdiction, however, Judge Coffin takes the basic federal-court line espoused in the recent draft of the Committee on Long Range Planning mentioned above, namely, that diversity jurisdiction in federal courts should be limited or eliminated with the possible exception of "actions involving aliens, interpleader actions, and cases in which the petitioner can clearly demonstrate local prejudice in the relevant state court," or for consolidated mass tort litigation. ${ }^{20}$ Judge Coffin suggests that diversity jurisdiction burdens the federal courts with one-fourth of their caseload and one-half of their jury trials, requires federal judges to engage in "arcane efforts" to guess at state law, flouts the basic idea of federalism, fosters the idea that state courts are second-rate, and removes incentives for the bar representing nonresident corporations to work for the improvement of state courts. ${ }^{21}$ Here I must intervene to say that on the subject of diversity jurisdiction-the abolition of which has been suggested at least since $1928^{22}$ and a subject that seems no closer to resolution today than it was six decades ago-it will remain a mystery to me why no one has seized upon the suggestion, first formally put forth in law review form by Professor David L. Shapiro, that the decision to retain, curtail, or abolish diversity jurisdiction should be made by each judicial district individually. ${ }^{23}$

Why has diversity at local district option not been taken up by more legal thinkers, movers, and shakers? Professor Shapiro's piece made the valid point-based on a survey of federal judges-that "diversity jurisdiction may be more warranted, and more useful, in some districts than in others," because federal districts "vary widely in population, urban or rural character, types of cases filed in the federal courts and docket congestion," and because there are different perceptions among judges in different districts about the quality of state justice afforded out-of-state litigants. ${ }^{24}$ To be sure, perhaps this has indeed crept indirectly into the Committee's thinking when, in their recommendation mentioned above, they make an exception for "cases in which the petitioner can clearly demonstrate local prejudice in the relevant state court."25 But it seems to me to border on the ridiculous if what the recommendation means is that in a given case an individual litigant should have to show that he, she, or it would be prejudiced by litigation in a state court. Such a proposal would create all kinds of strife, whatever is the opposite of "comity," and would be an impossible burden to meet in most cases, absent the existence of some "custom" or "practice," which would be equally hard to

20. PROPOSEd PLAN, supra note 13, at 25 (Recommendation 6).

21. ON APPEAL, supra note 2, at $64-65$.

22. See Henry J. Friendly, The Historic Basis of Diversity Jurisdiction, 41 HARV. L. REV. 483 (1928); HENRY J. FRIENDLY, FEDERAL JURISDICTION: A GENERAL VIEW 140-41 (1973).

23. David L. Shapiro, Federal Diversity Jurisdiction: A Survey and a Proposal, 91 HARV. L. REV. 317 (1977).

24. Id. at 339.

25. PROPOSED PLAN, supra note 13, at 25. 
prove ${ }^{26}$ How much better, how much less likely to cause friction, to have the individual districts determine whether or not to abolish, limit, or retain - within established parameters-diversity jurisdiction. Professor Shapiro's proposal, as refined, would be to give each district a choice, to be exercised by a majority of that district's judges on regular, active status, after adequate notice and opportunity for comment, among retention of the present scheme, adoption of the ALI proposal (to limit the invocation of diversity jurisdiction to those litigants who are in fact without substantial attachments to the forum state), and abolition of diversity jurisdiction altogether. ${ }^{27}$ Shapiro makes a strong argument that such a plan would be constitutional, at least insofar as the Congress is capable of delegating the power to make rules affecting jurisdiction. ${ }^{28} \mathrm{He}$ also answers affirmatively the question whether the courts are permitted by Article III to accept such a function, despite the dictum in Sibbach $v$. Wilson \& Co. to the effect that a court may not be given authority by rule to "extend or restrict the jurisdiction conferred by a statute." Professor Shapiro has indeed proposed a statute amending 28 U.S.C. $§ 1332$ to permit local-option diversity jurisdiction. ${ }^{30}$ This proposal has never caught on, although we have long taken Brandeis' view of the states as experimental laboratories. We have only ninety judicial districts within the fifty states and the District of Columbia. Like Professor Shapiro, I see no reason why those districts should not be seen as "suitable places for important experiments in judicial administration." ${ }^{\text {"3l }}$ Certainly, the all-or-nothing controversy that presently rages is a dead end, politically and otherwise. I rather wish that Judge Coffin had explored this alternative/compromise approach to the diversity problem.

I think Judge Coffin is at his very best when he gives us insights into his own thinking, into his own personality, if you will. This is particularly true in connection with his approach to decision making. But it is also true in his descriptions of his relationships with law clerks and with the other members of his court.

Particularly in reference to decision making, Judge Coffin gives us a genuine feeling of what it is like to be a sensitive, thoughtful, caring judge. He speaks of his "cyclical agony," 32 his "meandering perambulation toward decision" ${ }^{33}$ - something he calls "graduated decision-making." ${ }^{34} \mathrm{He}$ often

26. The public generally is aware of one major corporation that could not show such a custom or practice in the State of Texas, where judges run for reelection and evidently receive campaign contributions from the attomeys or law firms that appear before them.

27. Shapiro, supra note 23 , at $339-55$.

28. Id. at $341-48$.

29. 312 U.S. 1, 10 (1941).

30. Shapiro, supra note 23 , at 348-49.

31. Id. at 355.

32. ON APPEAL, supra note 2, at 110.

33. Id.

34. Id. 
uses sailing or navigational analogies, in his writing generally as well as in reference to his decision-making process. His "mind continually tacks like a sailboat going upwind." 35 Like all of us, he can be somewhat persuaded by reading the appellant's brief, but then persuaded the other way by reading the appellee's. Talks with law clerks cast doubts that might then be demolished by oral argument, only to be shaken in post-argument conference and then again in research and writing. Not until the opinion is filed are the doubts finally resolved, and even then one can rightfully wonder whether one's decision was correct. I have a name for the ultimate of this kind of case-a 50.001 case-where the decision-making process is excruciating and where the final result is only $50.001 \%$ satisfactory or persuasive to one's own mind and heart and the opposite conclusion carries with it the remaining $49.999 \%$ of wisdom and rectitude. Fortunately, one has these cases only once every year or two; otherwise, we judges might become empty shells. Three examples in my own experience include: United States ex rel. Jackson v. Follette, ${ }^{36}$ where two weeks spent by the writer in the Harvard Law School library stacks, exploring everything I could find on the subjects of double jeopardy and murder, failed to give me much of a clue as to whether retrial for felony murder constituted double jeopardy after conviction of premeditated murder, followed by reversal on habeas corpus; Harry Fox Agency, Inc. v. Mills Music, Inc. ${ }^{37}$ where in an almost unique reversal by our court of Judge Edward Weinfeld ${ }^{38}$ in an extraordinarily complex statutory construction case involving the derivative works exception to the termination-of-transfers provision of the Copyright Act of 1976, we attempted to affirm a congressional purpose without denying holders of derivative copyrights the protection given them by the exception, while nevertheless recognizing the interests of publishers and of the public as defined and balanced in the Act, only to have the Supreme Court disagree by as close a margin as possible; and Brander International, Inc. v. Cascade Pacific Lumber Co., ${ }^{39}$ holding on the "cutting-edge" question of "conceptual separability" that a bicycle rack design was not entitled to copyright protection, despite its superior design elements, because it could not be said to be conceptually separable from its utilitarian elements, a decision of which I am constantly reminded as I see the appellant's beautiful bicycle racks in good use in numerous places.

35. Id.

36. 462 F.2d 1041 (2d Cir.), cert. denied, 409 U.S. 1045 (1972).

37. 720 F.2d 733 (2d Cir. 1983), rev'd sub nom. Mills Music, Inc. v. Snyder, 469 U.S. 153 (1985) (5-4 decision).

38. "Almost unique" in the sense that Judge Weinfeld wrote with such care, precision, and scholarship that he very, very seldomly was reversed. I have written of him with awe in James L. Oakes, Grace Notes on "Grace Under Pressure", 50 OHIO ST. L.J. 701,702 (1989), a piece following Judge Coffin's lead in Frank M. Coffin, Grace Under Pressure: A Call for Judicial Self-Help, 50 OHIO ST. L.J. 399 (1989), where the judge identified nine areas of judicial stress, several of which are discussed in the book under review. 39. 834 F.2d 1142 (2d Cir. 1987). 
Judge Coffin discusses three such cases of his own, Drown v. Portsmouth School District, ${ }^{40}$ a case involving a nontenured teacher's not receiving a contract renewal, not reversed but overruled in Board of Regents of State Colleges v. Roth $;^{41}$ Fano v. Meachum ${ }^{42}$ involving a transfer from a medium security prison to a maximum security prison, reversed in Meachum v. $\mathrm{Fano}^{43}$ where the Supreme Court held that the transfer was not a serious enough infringement on liberty to trigger due process protections; ${ }^{+4}$ and Burbine v. Moran, ${ }^{45}$ involving false statements by police to a suspect's attorney that they were "through with him for the night," after which they proceeded to obtain inculpatory statements from the suspect. I am afraid I would have been less polite than Judge Coffin in discussing this last, outrageous Supreme Court decision. Nobody ever said that judging would be easy, especially when the cases are "hard."

I pause here to say that throughout the book, as well as in the judging process, Frank Coffin is truly a humble man. I cannot by saying anything improve upon his own language, where he discusses "follow-up tasks" that he performs after argument:

Even with the reading that I will have done, the reading my clerks have done, and the give-and-take of our seminars, $\left[{ }^{66}\right]$ I know that I will still feel inadequate as I hear difficult and complex cases being argued. I will admire colleagues who may have mastered a case with which I am still struggling and may say to myself, after a particularly brilliant intervention by a colleague, "I wish I had said that." But I remind myself that I should not despair, that it is too early to feel mastery, and that at least I have started the process that will eventually deliver me to the point of conviction about a decision.

He views the judge as "architect-editor" of the clerk's opinion drafts, but he also believes it important always to have on hand some opinions done entirely by the judge except for checking and editing by the clerks. ${ }^{47}$ I completely agree. His entire catalog of the cardinal responsibilities of the judge, such as threshold indoctrination, easy communication, responsibility, and feedback, as well as broad-brush editing, together with his account of the responsibilities of law clerks, are very models of what an appropriate clerk/judge relationship

40. 435 F.2d 1182 (1st Cir. 1970); see ON APPEAL supra note 2, as 290.

41. 408 U.S. 564 (1972).

42. 520 F.2d 374 (1st Cir. 1975); see ON APPEAL, supra note 2, at 291-92.

43. 427 U.S. 215 (1976).

44. This is also discussed in The Ways of a Judge. See WAYS OF A JUDGE, supra note I. at 179. 220. Some decisions hur.

45. 753 F.2d 178 (Ist Cir. 1985), reversed sub nom. Moran v. Burbine, 475 U.S. 412 (1986); see ON APPEAL, supra note 2, at 292-93.

46. He uses the word "seminars" to refer to his conferences with his law clerks.

47. ON APPEAL, supra note 2, at 194. 
should be, with the end result of "shared creativity" and "creative symbiosis"48 the consummation devoutly to be wished.

Judge Coffin's musings on collegiality, ${ }^{49}$ that oft-used but seldom-defined term, may be the best thing written on the subject. His definition, while done in hornbook style, is entirely apt. ${ }^{50}$

He speaks of collegiality as being endangered by the plethora of judges, noting that the more one sits with the same judge or judges, the greater the collegiality, with the converse also true. He contrasts his own halcyon days described in The Ways of a Judge, when he was sitting with the same people week after week, with the newer situation where the First Circuit consists of six active and four senior judges, and all of the other twelve courts of appeal have ten or more active judges and up to ten senior judges. ${ }^{51}$ I completely agree that nine times out of ten proximity makes the heart grow fonder, or, perhaps it should be put, makes the minds more compatible.

Judge Coffin is at his best when he talks about what can chill collegiality: the too-early hardening of a colleague's approach to a case; delay in responding to draft opinions or, I should add, in writing or circulating one's own opinions (can anything be more disheartening than to receive an opinion in a case that was argued eight or ten months previously when one has forgotten the issues and the fine points and the record and has to do double work just to comprehend the delayed opinion?); the use of irritating or pejorative or ad hominem language; lobbying by someone for a value-laden viewpoint; critical overkill, meaning unnecessarily making irritating suggestions as to style and substance without suggesting alternatives, or having law clerks fine-pick an opinion for every possible little weevil in the boll. ${ }^{52}$ I would add only the problem occasionally encountered, more perhaps by senior judges than by actives, namely, the overinterrogation of lawyers at argument to the point where either the lawyers are unable to make their arguments, or you as a judge are unable to ask any question that you may have in mind, or both. A hot court may be better than a cool court, but a "too hot" court can raise the temperature of one accustomed at least to equal participation in oral argument. I, for one, have seen more judges' anger raised

\footnotetext{
48. Id. at 209.

49. Id. at 213-29.

50. Judge Coffin describes appellate judicial collegiality as follows:

The deliberately cultivated attitude among judges of equal status and sometimes widely differing views working in intimate, continuing, open, and noncompetitive relationship with each other, which manifests respect for the strengths of the others, restrains one's pride of authorship, while respecting one's own deepest convictions, values patience in understanding and compromise in nonessentials, and seeks as much excellence in the court's decision as the combined talents, experience, insight, and energy of the judges permit.
} Id. at 215 .

51. Id. at 213-16.

52. Id. at 217-20. 
by undue or unfair interrogation in oral argument than by any written memo, discussion in confidence, or other exchange among members of the court.

Judge Coffin nicely points out that to encourage collegiality, an awareness of and appreciation for the strengths of colleagues must be demonstrated, as must an instinctive sensitivity to one's colleagues' sensibilities during the course of conversation or writing. There must be a responsive dialogue with suggestions that do not run only to style (I seldom make suggestions as to style except as I try to encourage my colleagues to drop the use/abuse of the pejorative word "mere"), and reaction to the suggestions of the other judge or judges in a constructive manner, avoiding either haughty rejection or servile acceptance. $^{53}$

In discussing the judging of appeals in nonroutine cases, i.e., in his metaphor where the navigation is in water with "uncharted depths," Judge Coffin avoids the not totally successful attempt made in his earlier book to give us a capsule of American jurisprudence. ${ }^{54}$ Rather, he discusses the "ageold issue of the proper balance between the rights of the individual and the interests of the state," 55 isolating and identifying his principal set of values, which govern when he is not tightly confined by precedent. These include liberty, equality, and "workability," as well as community. ${ }^{56}$ They are as simple but as well expounded in the pages of this book as may be found in more sophisticated jurisprudential literature. ${ }^{57}$ I will leave the reader to her own devices.

I am sure anyone reading this Review wants to ask the question of the reviewer, "Is there anything new in this book that was not in the earlier one covering similar subjects?" To be sure, Judge Coffin has come to a much greater acceptance of technology than he had in The Ways of a Judge, where he "suspend[ed] judgment on much of the sophisticated technology designed to spare us from our labors," book. ${ }^{59}$ The judge has gone from the use of yellow legal pads for opinion drafting to the use of a word processor. ${ }^{60}$ All the technology is there-as it is, so far as I know, in every judges' chambers-because it has to be in order to permit us to keep up with the workload. ${ }^{61}$ But Judge Coffin's underlying themes are the same, the underlying values are the same, the approach to judging is the same in 1994's On Appeal as it was in 1980's The Ways of a Judge, and this is not surprising. Why change a good thing? Frank Coffin is

53. Id. at 220-22.

54. See WAYS OF A JUDGE, supra note 1, al $206-46$.

55. ON APPEAL, supra note 2, at 280.

56. Id. at $281-86$.

57. See, e.g., RONALD DWORKIN, TAKING RIGHTS SERJOUSLY 81-130 (1977) (discussing "hard cases").

58. WAYS OF A JUDGE, supra note 1 , at 192.

59. James L. Oakes, On the Craft and Philosophy of Judging, 80 MiCH. L. REV. S79. 587 (1982).

60. ON APPEAL, supra note 2, at 68.

61. Id at $70-71$. 
a fine judge. His approaches to the art of judging appellate cases are as close to my own now as they were in the 1980's so that I can hardly be the one to criticize. Besides, what great artist has not built on his previous work? I have always found it difficult to determine whether I am listening to Brahms' First or his Second Piano Quartet; each incorporates much of the other's phrasing, melody, and general composition. How many legal academicians have said essentially the same thing in different ways in article after article? How many times did Monet paint the water lilies in his garden at Givenchy-often in similar ways-or how many times did Cézanne paint the Mont Saint-Victoire in Provence, perhaps in slightly different light, perhaps from a slightly different angle? Darwin's On the Origin of Species ${ }^{62}$ was derived from his voyage aboard the H.M.S. Beagle, after twenty years, and how many of the observations he subsequently was to suggest were already made evident in his ruminations about the voyage ? $^{63}$ I could multiply the examples.

Frank Coffin's newest book, even to those of us who read or even reviewed the earlier one, is an entirely worthwhile, constructive, delightful endeavor. I only wish that I had been able to write it.

62. Charles Darwin, ON THE ORIGIN OF SPECles (Modem Library 1936) (1859).

63. See British Museum (NATURAL History), Origin OF SPECIES 10-11 (1981). 